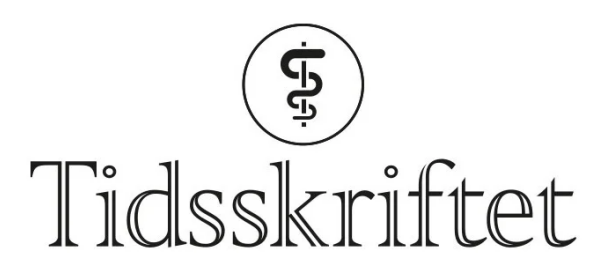

DEN NORSKE LEGEFORENING

\title{
Mottaksmedisin - akuttmedisinens sorte får
}

KOMMENTAR

\section{LARS PETTER BJØRNSEN}

Oddvar Uleberg (f. 1974) er konstituert avdelingssjef, overlege og spesialist i anestesiologi. Forfatter har fylt ut ICMJE-skjemaet og oppgir ingen interessekonflikter.

Email:larspb@me.com

Akuttmedisinsk fagavdeling

St. Olavs hospital

\section{ODDVAR ULEBERG}

Oddvar Uleberg (f. 1974) er konstituert avdelingssjef, overlege og spesialist i anestesiologi. Forfatter har fylt ut ICMJE-skjemaet og oppgir ingen interessekonflikter.

Akuttmedisinsk fagavdeling

St. Olavs hospital

\section{All akuttmedisinsk utredning og behandling i et akuttmottak kan betegnes som mottaksmedisin. Fagmiljøene må selv definere hva som er god klinisk praksis gjennom faglige vurderinger og retningslinjer.}

I Norge drives akuttmedisinen innen de prehospitale tjenestene, på legevakt og ved spesialisthelsetjenestens frontlinje: Akuttmottaket. Tradisjonelt er akuttmedisin blitt oppfattet som «blålysmedisin», men dette er et langt bredere fagområde hvor kun et mindretall av pasientene umiddelbart trenger tilsyn av anestesilege (1․). Akuttmedisin omhandler kunnskap og ferdigheter som er nødvendig i forebygging, diagnostisering og håndtering av alle akutte tilstander, både somatiske og psykiske (므). Det er derfor hensiktsmessig å definere all akuttmedisinsk utredning og behandling i et akuttmottak som mottaksmedisin.

\section{Norsk akuttmedisin}

I den akuttmedisinske kjeden er tidsfaktoren er viktig. Mangelfulle ressurser tidlig i kjeden kan ikke kompenseres fullt ut ved godt utbygde tjenester senere (3). Utfordringen i Norge er heller det motsatte: Økte ressurser og kompetanse prehospitalt vil ikke kunne kompensere for inadekvat og ustrukturert behandling i akuttmottakene (4).). Alle leddene 
i behandlingskjeden er like viktige, og faller ett ut, vil det kunne påvirke pasienten negativt. Det mangler en enhetlig forståelse av hva akuttmedisin er, og det finnes ingen enhetlig kompetanseplan innen fagområdet, slik man har i mange andre land.

Regjeringen ønsker å sikre likeverdig tilgang til nødmeldingstjenesten (5), og det er satset mye på økt kompetanse innen de prehospitale tjenestene (3). Det er utviklet en kompetanseplan for personell som mottar og håndterer medisinske nødmeldinger (므), Nasjonalt kompetansesenter for legevaktmedisin ble opprettet i 2004 (7) og luftambulansetjenesten har en nasjonal standard for luftambulanseleger ( $\underline{8})$. Det er ingen grunn til at det ikke skal stilles kompetansekrav også til leger som jobber i akuttmottak. I en dansk undersøkelse fra 2010 hadde de som mottok pasienter ved akuttmottak, i gjennomsnitt bare rundt tre måneders erfaring som lege, og de konfererte sjelden med mer erfarne kolleger (9.). Resultatene er overførbare til norske sykehus.

\section{Manglende kompetanse}

Helsetilsynet fant ved tilsyn i 2007 at mange pasienter opplevde uforsvarlig behandling og lange ventetider ved norske akuttmottak (4). Dette skyldes både måten akuttmottakene er organisert på og manglende breddekompetanse. Akuttmottakene er sykehusenes inngangsport for de fleste akutte og uselekterte pasienter, likevel har denne viktige delen av den akuttmedisinske kjeden vært lite omtalt. Struktur og ansvarsfordeling i norske akuttmottak er i dag den samme som i 2007. Behandlingsrutiner og prosedyrer er fragmenterte og bestemmes av ulike spesialiteter. I enkelte tilfeller kan samme tilstand bli behandlet forskjellig avhengig av hvilken spesialitet som får ansvaret.

I samhandlingsreformen er hovedintensjonen rett behandling på rett sted til rett tid (10). Dette forutsetter at det helsepersonell som skal behandle akutt syke mennesker, har nødvendig akuttmedisinsk breddekompetanse, uavhengig av organisering.

Når nye leger med varierende kompetanse og erfaring er de første som møter pasienten, må sykehuset sikre kompetansen ved systematisk opplæring i oppgaver og rutiner i akuttmottaket, og man må ha fleksible og robuste ordninger med lav terskel for å tilkalle mer erfarne leger (4).

I en offentlig utredning omtales manglende kompetanse i akutt mottakene, men ikke hva en lege i akuttmottaket skal inneha av kunnskap og ferdigheter (3). Det er satt standarder for organisering og ledelse av akuttmottak (1ㅡ), men det er til nå ikke stilt krav til akuttmedisinsk fagkompetanse på legesiden.

Den nye nasjonale helse- og omsorgsplanen angir retningslinjer for hvordan regjeringen $\emptyset$ nsker å sikre effektiv og adekvat pasientbehandling (5). Helsedirektoratet får her i oppdrag å utrede muligheten for akuttmedisin som et kompetanseområde, slik man har i Danmark.

\section{Kompetanseplan}

Norsk selskap for akuttmedisin (NORSEM) jobber for å bedre den medisinske kompetansen i norske akuttmottak. På sikt er det ønskelig å etablere akuttmedisin som egen spesialitet, slik det er i over 6o land. Det er utarbeidet et utkast til en norsk kompetanseplan for akuttmedisin (므). Målbeskrivelsen gjelder primært utredning og behandling i akuttmottak (mottaksmedisin), men er også aktuell for legevaktmedisin. Kompetanseplanen legger også opp til utvikling av kurs og fagmateriell.

En lege i et akuttmottak må benytte en symptombasert og fokusert tilnærming til den enkelte pasient. Det er viktigere å utelukke livstruende tilstander enn å komme frem til en presis diagnose. Legen må også være en kompetent lagspiller, ettersom mottaksmedisin 
utføres best i team. Trygge og forutsigbare rammer i undervisning og opplæring er nødvendig for leger under spesialistutdanning - man skal lære av sine feil, men ikke la det gå utover pasientene.

Publisert først på nett 30.3. 2012

\section{LITTERATUR}

1. Nordseth T, Skogvoll E, Gisvold SE. Anestesiologisk akutthjelp i sykehus. Tidsskr Nor Lægeforen 2005; 125:3124-6. [PubMed]

2. International Federation for Emergency Medicine (IFEM). www.ifem.cc (5.3.2012)

3. Norges offentlige utredninger. Hvis det haster... Faglige krav til akuttmedisinsk beredskap. NOU 1998: 9 .

4. «Mens vi venter...»-forsvarlig pasientbehandling i akuttmottakene? Oslo: Statens helsetilsyn, 2008.

5. St.meld. nr. 16 (2010-2011). Nasjonal helse- og omsorgsplan (2011-2015).

6. Dreyer K, Jensen ÅC, Almenning B. Kompetanseplan for personell som mottar og håndterer medisinske nødmeldinger. Bergen: Nasjonalt kompetansesenter for helsetjenestens kommunikasjonsberedskap, 2011.

7. Nasjonalt kompetansesenter for legevaktmedisin. www.helse.uni.no/Default.aspx?site=8 (5.3.2012).

8. Nasjonal standard for luftambulanseleger (helikopter). Oslo: Luftambulansetjenesten, 2011.

9. Folkestad L, Brabrand M, Hallas P. Supervision og arbejdsfordeling ved modtagelse og videre behandling af akutte medicinske patienter. Ugeskr Læger 2010; 172: 1662-6. [PubMed]

10. St.meld. nr. 47 (2008-2009). Samhandlingsreformen. Rett behandling - på rett sted - til rett tid.

11. Veiledning til ISO goo1: 2008 for akuttmottak. NA Dok. 58. Oslo: Norsk Akkreditering, 2010.

12. Bjørnsen LP, Uleberg O. Kompetanseplan for akuttmedisinsk fagområde i Norge. Oslo: Norsk selskap for akuttmedisin, 2011. www.norsem.no (5.3.2012).

Publisert:30. april 2012. Tidsskr Nor Legeforen. DOI:10.4045/tidsskr.12.0208 Mottatt 15.2. 2012 og godkjent 8.3. 2012. Medisinsk redaktør Petter Gjersvik.

(C) Tidsskrift for Den norske legeforening 2023. Lastet ned fra tidsskriftet.no 26. april 2023. 